DOI: $10.1515 / \mathrm{abcsj}-2016-0017$

\title{
Strangers on the Doorstep: Hostility and Hospitality in A Distant Shore
}

\author{
CHING-HUAN LIN
}

National Central University, Taiwan

\begin{abstract}
This article focuses on the rising hostility against immigrants / refugees and growing demand for hospitality, in both regional and transnational senses, in Caryl Phillips's novel A Distant Shore, set in a local place in North England. I think that the author, in examining the parallel conditions of being a stranger in a village and an outsider to the nation, shows that the demands of hospitality are similarly urgent whether sought by nationals or foreigners though these are calibrated differently in terms of scales of belonging. My broader argument is that hospitality is an ethical practice of everyday life that requires continual renegotiation. Inspired by Levinasian ethics, I turn to Derrida's and Rosello's meditations on hospitality, which emphasise the metaphorical nature of the host-guest relationship and the tension it inscribes between the finiteness of politics and the infinity of ethics. By exploring the complex relationship between politics and ethics as this is made manifest in the literary representations of ordinary British citizens' everyday practices, I suggest that this novel not only deals with the UK's domestic tensions of multiculturalism and ethnic conflict, but also critically reflects on its bewildered (but hardly new) attitude toward the ongoing transnational integration of the new Europe in the postwar period.
\end{abstract}

Keywords: Caryl Phillips, Europe, refugee, immigrant, national identity, hospitality, ethics, transnational migration, racism, mobility

Caryl Phillips's works can be considered in many ways as a manifestation of the history of black Europeans. ${ }^{1}$ A Distant Shore focuses on the immigration of refugees to modern England in the late 1990s. By placing his protagonists within the wider context of the black (African-Caribbean) 
diaspora, Phillips offers transnational perspectives on European migration and belonging that reflect, in turn, on what it means to be European at different stages of the continent's past. The arrivals of blacks through different routes by different ways at different times also reflect the successive changes in Europe's geopolitical map and its tight connection with the peripheral zones. No single region or time in Europe is pure, without boundary crossing. By mapping the transnational and transtemporal movements of black peoples, Phillips's novels also foreground their involvement in the representation of Europe's constructed identities and the broader cultural patterns within which those representations are framed.

In his more recent work, however, Phillips has a tendency to focus on the region. ${ }^{2}$ A Distant Shore, for example, is set in a small town in northern England, while the last section of Foreigners is located in the provincial city of Leeds. ${ }^{3}$ By 'region' I do not mean that these locations are of minor significance, rather that their scale is smaller in comparison to the nations, continents and empires that form the social, political and geographical background to his earlier works. I have no wish here to undermine the transnational dimensions of Phillips's works, which are often read as counteracting the parochialism of nationalist racisms. In fact, Phillips's regional settings might be seen, to some extent at least, as staging post-national conditions in Europe, which are shaped by the triangulation of global flows, transnational entities (especially the EU), and region-based nationalisms. Far from bringing Britain and continental Europe closer together, these conditions have produced animated disagreements about EU migration policy, leading for example to debates about what to do with would-be asylum-seekers looking to smuggle themselves into England on cross-Channel trains and ferries. Britain's and France's shared unwillingness to deal with people foreign to them has made identity politics on both sides of the Channel more complicated, though not necessarily less embattled, than the mere repetition of ancient histories of Anglo-French animosity might suggest. Britain, for its part, often portrays these people as intruders to the country, while their presence also provides an unwanted reminder of the ever-increasing 
power of the EU and a continuation of the territorial losses associated with the end of Empire.

In the recent history of Britain, debate - and the moral panic it sometimes spawns - about race and difference has tended to centre on the metropolis. However, public disquiet has now arguably shifted to regional towns like Margate and Dover; and, as a result, costal territories have become the new frontier for defenders of contemporary nationhood and rights for whites. By reading A Distant Shore within the context of a small region (by which I mean a physical idea - a dwelling place where a person's everyday life and relational networks are physically grounded as well as a symbolic concept - the space of belonging where a subject is able to root or re-root psychically), my purpose in this article is to see the region as a confronting zone of racism as well as a starting point for the ethical imagination. As I hope to show, in A Distant Shore it is in the ambivalent region, where different peoples interact, that the distance between local and global is traversed and the colour line is drawn and redrawn.

A Distant Shore depicts the encounter between an alienated white woman and an alienated black man, the latter of whom is later violently attacked and murdered. Dorothy is a newly retired, divorced music teacher who has recently moved back to the small town she grew up in, while Gabriel/ Solomon is a refugee recently arrived from Africa and now working as a night watchman. By comparing the condition of being a stranger in a village to that of being an outsider in a nation, the novel asks us to think about several scales of belonging, all of which are linked with the issue of place. Place, indeed, is at the very centre of the novel. At the beginning, we are introduced to a place called Weston, which is reluctantly undergoing a name-change because of new development. What makes this rather dull village - "the biggest thing that had ever happened [here] was Mrs. Thatcher closing the pits, and that was over twenty years ago" (4) - meaningful is its historical connection with other European towns. It is twinned with a German town that was almost razed to the ground by the RAF during World War II and a French village whose Jewish inhabitants, once in the majority, were sent to the concentration camps during the same period (4). However, Phillips hints that the local 
residents' insistence on the town's original name derives from their pride in being removed from Europe. The identity of the town, as Rebecca Walkowitz points out, "seems to depend on its status as a place where bombing and deportation did not take place" (542).

By contrasting the brave military action conducted by the Royal Air Force with the disgraceful support for the Nazis in occupied France, Phillips implies that a kind of "ethical superiority" lurks somewhere in the residents' collective mind-set: they are proud of the town's 'remoteness', even if this remoteness "makes [it] a bit tame" (4). Weston, however, is not as tame - nor indeed as remote - as many of its inhabitants believe it to be. The perception of remoteness can also be interpreted as an act of historical denial, reminiscent of Britain's blindness to its own racism. Meanwhile, Weston's complacency in the historical victory over Nazism can be seen in terms of what Paul Gilroy calls

a rejection of deferral of its present problems. Neither the appeal of homogeneity nor the antipathy toward immigrants and strangers who represent the involution of national culture can be separated from underlying hunger for reorientation. Turning back in this direction is also a turning away from the perceived dangers of pluralism and from the irreversible fact of multiculture. (After Empire 97)

By referencing Weston's civic twins to the war experiences, this small town is suffering from what Gilroy has called "post-imperial melancholia", a syndrome rooted in past victories and the inability to adapt to the profound changes in circumstances and mood that followed the end of Empire.

The novel opens with the deceptively simple comment: "England has changed" (3). As the narrative progresses, we can certainly see the alteration of rural landscapes, the renaming of the town, and changes in demography, but we also begin to realise that - attitudinally at least England has not changed a lot. Instead, the country appears to be racked by enduring social tensions: confusions of national identity, an unfixed sense of belonging, persistent racial conflicts. The instances of racism that we witness in the novel - from threatening letters and graffiti, and excrement being pushed through someone's letter-box, to muggers - are 
characteristic of a volatile post-war social climate that continues to be heavily influenced by the exclusivist directives of the nation-state.

The obliviousness of the town to its own prejudices shapes the residents' hostile attitude towards 'outsiders'. The landlord of the local pub is a typical Westoner, who believes that Solomon's death is an accident because "nobody in Weston would do anything like this" (48). As he tells Dorothy: "If you've lived here as long as I have ... and you've grown up with folks like these, you'd understand that there's not one among them capable of harming anybody. That's just how they are. Decent folk committed to their families and their community" (48-9). Meanwhile, Dorothy's sedentary father, anxious about his Englishness, is always "bemoaning the fact that we were giving up our English birthright and getting lost in a United States of Europe" (27). He demonstrates strong racial prejudice, not only to people of colour - "a challenge to our English identity" - but also to other ethnic groups: the Welsh, for example, he finds to be "full of sentimental stupidity [while] the Scots [are] hopelessly mean and mopish ... and the Irish [are just] violent, Catholic drunks" (42). For him, being English means, emphatically, "no coloureds" (42).

The novel traces the connections between such routine abuse, later extended to the Indian newsagent Ranjit, and the extreme attack that causes Solomon's death and his dumping in the local canal. Violence is similarly linked to anxiety over belonging at a time when "it's difficult to tell who's from around here and who's not. Who belongs and who's a stranger. It's disturbing. It's doesn't feel right" (3). The town's increasing inability to distinguish a newcomer from a local also helps us to understand the alienated conditions of the novel's two protagonists. Before Solomon comes to knock on Dorothy's door and start their friendship, they are completely lonely. He is a black man and, as such, is unaccepted by the community; while she is isolated from people because of her mental illness. Both are aware of being the subject of conversations that people of Weston feel comfortable enough to conduct but that none of them really cares about. Dorothy's health condition, her retired life, and her private relationship are all topics of gossip: "it's a small village ... [T]hese people, they talk" (23). Her unwillingness to blend in with the 
local residents is like Solomon's inability to integrate into the community: both are abnormal to this quintessentially ordinary town.

Their alienation from society can also be traced in the different perspectives they use to look at the world. In many scenes, Dorothy sees the outer world from behind a shield of glass - the window of a building, at the pub or her own house, or the windscreen of Solomon's car or a bus. The world seen this way is transparent; everything seems to unfold before the observer but at the same time to be remote, inaccessible or unrelated. On her way back to the town from the seaside, Dorothy looks outside over the driver's shoulder, finding "nothing inviting" about the "dull and uneventful" landscapes (58). Dorothy's life in Weston is like moving from one transparent box to another: there is much to see, but communication is out of reach. Only when she is in the graveyard to visit her dead parents does she reveal more of her thoughts. But talking alone in the graveyard is regarded as evidence of her disorder, which removes her from people further. If suspicion makes Dorothy seal herself in her own world, the hostility towards Solomon drives him to retreat to his bare bungalow. Like Dorothy, he looks at the world cautiously, from behind the blinds, but he is powerless to prevent the threat on his doorstep abusive letters with razors inside, dog mess in his mailbox and, eventually, a deadly knock on his front door.

By comparing the man's direct experience of racism with the woman's acute loneliness, Phillips suggests that the town's exclusion of strangers, like the woman, is not so different from the motives involved in attacking a foreign man. In fact, these two kinds of hostility arguably derive from the same source of nativist or tribal thinking. Dorothy comes back to her hometown for emotional refuge when her life hits rock bottom - forced retirement, fruitless relationships, and the passing away of her younger sister. Meanwhile, Solomon, escaping from the massacre of the civil war in his country, resettles with the help of the Anderson family and restarts his life in England. Both are left alone in a world with unbearable traumas. Through their stories, we eventually discover that the woman is as rootless as the man. Both are displaced, both seeking refuge in their own way. 
Phillips's concern for humanity extends beyond his individual characters' inner and outer ordeals. As McLeod notes, the novel is "concerned centrally with the temporary yet invaluable encounter between tangential peoples that evidence their myriad, unexpected, yet day-to-day participation in each others' lives", and this opens up a possibility for ethical interaction, even if such interaction is hugely fragile and continually obstructed by "prejudicial barriers" of all kinds ("Diaspora and Utopia" 12). Perhaps the best example is the way in which Gabriel/ Solomon turns his initial dislike of Denise into eventual empathy for her and a growing understanding of the pain she has suffered in her life. McLeod argues that such everyday kinds of interpersonal engagement and support possess a more progressive and transformative meaning than more spectacular, state-sanctioned celebrations of multicultural flux. As a consequence, he suggests, Phillips directs our attention to the "endless proliferating tactics of everyday life, which are proffered not as political stratagems but as an ethical imperative" (13-4). In what follows, I would like to further test this ethical imperative - which, after Levinas, I will locate in the everyday experience of negotiating between infinity and finiteness - by looking at the demands of hospitality and both the possibilities and limitations it provides.

On the morning when the lorry driver Mike brings Solomon home, Mr. Anderson is eating his regular breakfast. His reactions to a stranger's unanticipated arrival are unflustered:

"Well, sit down. We'll get you some breakfast, then find you somewhere to put your stuff." The man returned to reading his newspaper. It was a very large newspaper, and I notice that he seemed to be experiencing some difficulty folding the paper into a proper shape. Curiously enough, his problem was occupying him more than the strangeness of a foreign person having crossed his threshold. (277)

Soon after Anderson and Mike have finished their breakfast and left, Anderson's wife is left alone with the stranger. Sitting in an ordinary kitchen, and accompanied by a woman standing by the sink, her hands full of soapy water, Solomon proceeds to tell her stories about the plight of his country, and about his hard journey to England and his equally hard experiences there, which he has never revealed to anyone before. The 
Anderson family not only offer the best hospitality they can, they later help him to transfer his residence status to legal. However, this hospitality, generous though it is, fails to eradicate suspicion. Solomon appreciates the favours that are being shown him, but he has extreme difficulty in believing that such generosity might be given out of a pure desire to help. After such a long journey, he has finally met someone who is willing to understanding his suffering, but he dares not tell the whole story because he fears being betrayed. Allowed to live with the Anderson family before finishing his asylum process, and also promised some unofficial work, Solomon cannot believe his own good fortune: "I look at the woman and attempt to fathom her motives. Would she and her husband receive some special reward? If so, then I would not begrudge them their bounty, for my sole desire was to be safe in England" (279). Still distrustful, Solomon conceals those stories that might compromise his welcome significantly his aggressive army nickname "Hawk", his robbery-and-assault of his good friend, his rape charge in England. These things happened when he was still called Gabriel; and it seems entirely reasonable to believe that if Mrs. Anderson had learned of these 'Gabriel stories', she might have curtailed her hospitality or even thrown him out of the house. This episode demonstrates what ideal hospitality consists of, but also paradoxically implies that even an extreme form of hospitality is also a form of mistrust since it coexists with exclusion and can easily be betrayed. The host takes risks, but so does the guest.

By highlighting a multiple but contrary character - a soldier as well as a victim of a civil war, a criminal of murder and burglary but a good man with refined manners - Phillips succeeds in complicating our understanding of the ethical demands of hospitality and the relationship between those who give and receive it: benefactor and beneficiary; host and guest. He also complicates the view of hospitality as a (proimmigrant) counter-discourse to (anti-immigrant) state preventionism, featuring a mutually beneficial relationship between the generous host and the polite, industrious guest. Hospitality, Phillips suggests, is altogether more ambiguous and unstable than this. A brief aside on Derrida's important writings on hospitality may help us understand why. 
In his reading of Levinas's Totality and Infinity, Derrida argues that Levinas has bequeathed to us an "immense treatise on hospitality": the conjunction of an ethics of pure prescription with the idea of an infinite and absolute hospitality, Derrida argues, confronts us with one of the most pressing political, juridical and institutional issues of our time. Derrida's crucial distinction is between an ethics and a politics of hospitality. $\mathrm{He}$ sees the former as being infinite and beyond any human law, while the latter inevitably "involves limits and borders: calculation and management of finite resources, finite number of people, national borders and state sovereignty" (Rosello 11). However, these seemingly incompatible concepts are effectively inseparable in Phillips's novel. Throughout the novel, the 'infinite' ethical horizon of hospitality is in almost constant tension with the 'finite' demands of politics. In explaining his concerns to Solomon, Mr. Anderson cites the example of country's crowded hospitals: "It's just that this isn't a very big island and we don't have that much room. People think that other countries should take you first because we've done our bit ... Some folk think ... [t] hat you just want an easy living, or that you have too many children. They think you don't really want to work" (289). These concerns correspond to a common-sense wisdom about the need for thresholds and "acceptable percentages" of migration that is articulated forcefully by Mike, who is afraid of "living in a foreign country" if nobody "puts an end to all this immigration" (290).

Another factor in the novel that further complicates the concept of hospitality is the need to distinguish hospitality from the 'gift' or the process of material exchange. ${ }^{4}$ At first sight, the Andersons' warm welcome to Solomon is unconditional. Since the rainy night when Mike first opened his lorry door to a stranger, bought him food, and finally offered him long-term accommodation in his family's house, all the favours bestowed upon Solomon have been given to him like gifts, without any thought of recompense or repayment. But this hospitality is linked, not just to sympathy for Solomon's past but also to his likely productivity in the future: "You see, you're in a different situation ... You're escaping oppression and that's different. ... I mean, you're working. You're not a scrounger" (290-91). 
Solomon's potential contribution to society and his economic productivity become the very conditions that vouchsafe his hospitality. As Rosello points out, the ambiguity of hospitality is evident in its split between two idealised processes of negotiation: "ethically, hospitality is imagined as an infinite, unconditional, selfless, and endless gift (of your time, of your space, of your resource) on the one hand; politically, it can be conceptualized as a well-balanced exchange of mutual services" or benefits, on the other (52). Working may be one way of protecting the host-guest relationship from abuse, but being a guest always implies an expectation to leave, even in unconditional forms of hospitality. The guest is warmly welcomed, is made to feel at home, but is continually reminded that this is not home at all. The host is generous because he realises that it is only a temporary visit and the guest will leave sooner or later. From this perspective, infinite hospitality is precipitated back on its own finite boundaries, while even the initial welcome can be seen as asserting the authority of ownership, the mastership of the house. Hospitality reinforces the fixed relationship between the host and the guest, or, as Derrida puts it tellingly:

To dare say welcome is perhaps to insinuate that one is at home here, that one knows what it means to be at home, and that at home one receives, invites, or offers hospitality, thus appropriating a space for oneself, a space to welcoming the other, or, worse, welcoming the other in order to appropriate for oneself a place and then speak the language of hospitality. (Adieu to Levinas 15)

In A Distant Shore, the distinction between host and guest is tested to its limits and becomes interchangeable. With the help of the Andersons, Solomon obtains the legal right to stay in the country and is employed in the bungalow as a night watchman. This means he is given ownership of a house and has the capability to offer hospitality, as he does when he invites Dorothy for a cup of tea at his place. But the law cannot protect his status since he is still, officially, an uninvited guest. In the end, his life is cut short by some local young people after another ironically unlawful entry. Through the tragic case of Solomon, Phillips neither confirms the impracticability of hospitality nor articulates the incompatibility between ethical and political forms of hospitability; instead, he makes readers 
rethink what hospitality is and opens up a possibility of shifting between these two types. As Rosello comments sharply, "hospitality as metaphor blurs the distinction between a discourse of rights and a discourse of generosity, the language of social contracts and the language of excess and gift-giving" (9). Hospitality as a practice of ethics is always negotiated between the two poles of absolutely gratuitous gift (an ideal of ethics) and impeccably equivalent exchange (the politics of justice or the principle of economy). Only through the asymmetrical demand from the other and the absolute sacrifice of the self can the infinity of ethics be manifested and maintained.

Solomon's situation reflects the contest between a hospitality of invitation and a hospitality of visitation. In the former, only those who are invited and recognized as guests will be hosted, whereas the latter leaves one's house open to the unanticipated arrival. Although the conditional hospitality is premised on the moral equality of each person, it entails, in Will Kymlicka's word, "embarrassment" over conventional congruence of citizenship and territory boundaries with which ethical obligations have been inscribed into the procedures of public political deliberation, legal procedures and administered law (249). Regarding the predicament of enacting the virtues of hospitality within European countries, Derrida's absolute ethical appeal for the opening of a space into which the new arrivals can be admitted reminds us that the process of hospitality is not a fixed dichotomy, but a continuous shifting and shuttling of perspectives. Due to "the impossibility of waiting for the end of reflection," there is a need to take immediate action "with the utmost urgency" at the moment of undecidability (298). Upon the ideal of unconditionality, we might rethink the interrupting presence of the unforeseen arrivals and wonder if the nation state is still the requisite vehicle for enacting hospitality especially facing the humanitarian and political crisis within European countries.

By selecting two places implicated in Nazi crimes to represent Germany and France, respectively, and by clearly linking these to Weston, Phillips asks us to consider the difference between what we assume about English hospitality and what we learn about the actual treatment of strangers, in England and elsewhere. Phillips is skilled in juxtaposing different experiences in order to display the multiple connections and 
entanglements between his characters. The plot of A Distant Shore revolves around similar rejections of very dissimilar kinds of strangers. These figures include a local shop owner from Pakistan, an Irish doctor with a Jewish surname, and, most prominently, a male refugee from Africa and a retired teacher suffering from a psychological disorder. By comparing these strangers, and by comparing anti-immigrant racism to other systems of racism, Phillips blurs the boundaries between who is an insider and who an outsider, who is included and who excluded. Elsewhere, he writes of a new order

in which there will be one global conversation with limited participation open to all, and full participation available to none. In this new world nobody will feel fully at home. ... In this new world order of the twentyfirst century we are all being dealt an ambiguous hand, one which may eventually help us to accept the dignity which informs the limited participation of the migrant, the asylum seeker, or the refugee. ( $A \mathrm{New}$ World Order 5-6)

In a small town like Weston, even the locals are unable to "feel fully at home," but this only leads them to vent their frustrations on unsolicited migrants. A Distant Shore emerges, not only as a nuanced examination of current debates on hospitality in Europe, but also as a powerfully ambivalent analysis of the situation of the irregular migrant in a radically unstable new world. As Phillips's work suggests, the presence of crossChannel refugees is fundamental to the make-up of a British society whose renewed anxieties about strangers are inextricably tied to its shifting attitudes to Europe at local, national and transnational levels. This regional novel, I suggest, offers a window onto contemporary debates about human rights, social integration, multiculturalism and citizenship not only about the domestic situation within the UK, but also, in a broader sense of EU, about the sizzling discontent of member countries when facing unprecedented population movements recently. In other words, the recent acrimonious dispute over the relocation scheme is not really about numbers, but rather a concern over member state sovereignty and its close tie to identity. In light of ideas of hospitality, this novel shows that state interest and local ethics of hospitality are always in tension. To emphasize the contradictory logic of hospitality is not to suggest the failure of policy, 
but instead, upon the call of absolute hospitality, to foster new ways of inclusion which we may simply not recognize yet.

\section{Notes:}

${ }^{1}$ In fact, treating his writings in chronological order, we can trace the whole history of black Europe from the fifteenth century to the present. The first period is epitomised by Othello in The Nature of Blood, whose first-person narrative tells the story of his movements in and around the Mediterranean in the fifteenth century. Cambridge depicts the first arrival of blacks in England during the heyday of British colonial expansion in the nineteenth century. The Final Passage represents the post-war migration of West Indians after 1948, which brought Phillips himself to Britain as a child.

${ }^{2}$ In his recent research of landscape and narrative design, David James also notices how the contemporary regional novel finds new horizons through the interface of spatial politics and provincial realism in the face of globalism. See Contemporary British Fiction and the Artistry of Space (London: Continuum, 2008).

${ }^{3}$ Phillips's more recent novel In the Falling Snow (2009) deals with the life crisis of a black white-collar, middle-aged male Londoner.

${ }^{4}$ The theme of hospitality plays an important part in Derrida's philosophy. This concept reflects his lifelong interest in the rhetoric of the impossible. "The gift is the impossible," he argues in "The Time of the King" (124); and elsewhere he writes: "For there to be a gift, there must be no reciprocity, return, exchange, counter gift, or debt. If the other gives me back or owes me or has to give me back what I give him or her, there will not have been a gift" (Given Time 12). As long as a gift is taken as a gift, the essential meaning of the gift, to be given and received with no moral obligation, will soon be erased. Hence the paradox is that there will be no gift if a gift is taken as a gift.

\section{Works Cited}

Back, Les and Anoop Nayak, eds. Invisible Europeans?: Black People in the "New Europe." Birmingham: All Faiths for One Race, 1993.

Balibar, Étienne. "At the Borders of Citizenship: A Democracy in Translation?" European Journal of Social Theory 13.3 (2010): 315-22.

Blake, Andrew. "Writing on the Edge: Britishness and Its European Otherness." Text and Nation: Essays on Post-colonial Cultural Politics. Ed. Andrew Blake and Jopi Nyman. Joensuu, Finland: Faculty of Humanities, University of Joensuu, 2001. 14-28. 
Clingman, Stephen. ““England Has Changed”: Questions of National Form in $A$ Distant Shore." Moving Worlds: A Journal of Transcultural Writings 7 (2007): 46-58.

Critchley, Simon and Robert Bernasconi, eds. The Cambridge Companion to Levinas. Cambridge: Cambridge UP, 2002.

Derrida, Jacques. The Other Heading. Trans. Pascale-Anne Brault and Michael Nasa. Bloomington and Indianapolis: Indiana UP, 1992.

---. Adieu to Emmanuel Levinas. Trans. Pascale-Anne Brault and Michael Nasa. Stanford: Stanford UP, 1999.

---. "The Time of the King." The Logic of the Gift. Ed. Alan D. Schrift. New York \& London: Routledge, 1997. 121-47.

---. Given Time: I. Counterfeit Money, Trans. Peggy Kamuf. Chicago: University of Chicago Press, 1992.

Gilroy, Paul. After Empire: Melancholia or Convivial Culture?. London: Routledge, 2004.

---. Postcolonial Melancholia. New York: Columbia UP, 2005.

Kymlicka, Will. "Territorial Boundaries: A Liberal Egalitarian Perspective." Boundaries and Justice: Diverse Ethical Questions. Ed. David Miller and Sohail H. Hashimi. Princeton, NJ: Princeton UP, 2001. 249-75.

Ledent, Bénédicte. "The "Aesthetics of Personalism" in Caryl Phillips's Writing: Complexity as a New Brand of Humanism." World Literature Written in English 39.1 (2001): 75-85.

Levinas, Emmanuel. The Levinas Reader. Ed. Seán Hand. Oxford: Blackwell, 1989.

McLeod, John. “'Between Two Waves': Caryl Phillips and Black Britain.” Moving Worlds: A Journal of Transcultural Writings 7 (2007): 9-19.

---. "Diaspora and Utopia: Reading the Recent Work of Paul Gilroy and Caryl Phillips." Diasporic Literature and Theory - Where Now? Newcastle upon Tyne: Cambridge Scholars, 2008. 2-16.

Phillips, Caryl. A Distant Shore. London: Secker \& Warburg, 2003.

---. A New World Order: Selected Essays. London: Secker \& Warburg, 2001.

---. In the Falling Snow. London: Harvil Secker, 2009.

Rosello, Mireille. Postcolonial Hospitality: The Immigrant as Guest. Stanford: Stanford UP, 2001.

Schrift, Alan D., ed. The Logic of the Gift: Toward an Ethic of Generosity. New York: Routledge, 1997.

Shackleton, Mark, ed. Diasporic Literature and Theory - Where Now?. Newcastle upon Tyne: Cambridge Scholars, 2008.

Walkowitz, Rebecca L. "The Location of Literature: The Translational Book and The Migrant Writer." Immigrant Fictions [Special Issue], Contemporary Literature 47.4 (2006): 524-45. 